\title{
Vitrification of Nuclear Waste Calcines by In-Can Melting
}

by

H. T. Blair

May 1976

This paper is based on work performed under U.S. Energy Research and Development Administration Contract E(45-1): 1830 . 
NOTICE

This report was prepared as an account of work sponsored by the United States Government. Neither the United States nor the United States Energy Research and Development Administration, nor any of their employees, nor any of their contractors, subcontractors, or their employees, makes any warranty, express or implied, or assumes any legal liability or responsibility for the accuracy, completeness or usefulness of any information, apparatus, product or process disclosed, or represents that its use would not infringe privately owned rights.

\section{PACIFIC NORTHWEST LABORATORY}

operated by

BATTELLE

for the

\section{U.S. ENERGY RESEARCH AND DEVELOPMENT ADMINISTRATION \\ Under Contract AT(45-1)-1830}

Printed in the United States of America

$$
\text { Available from }
$$

National Technical Information Service

U.S. Department of Commerce

5285 Port Royal Road

Springfield, Virginia 22151

Price: Printed Copy \$5.45; Microfiche $\$ 2.25$ 
BY IN-CAN MELTING

H. T. Blair

May 1976

Battelle-Northwest

Pacific Northwest Laboratories

Richland, Washington

This paper is based on work performed under U.S. Energy Research and Development Administration Contract $\mathrm{E}(45-1): 1830$ 
BNWL-2061

UC -70

\title{
VITRIFICATION OF NUCLEAR WASTE CALCINES \\ BY IN-CAN MELTING
}

\author{
H. T. Blair
}

Vitrification of nuclear waste calcines using the storage canister as the melting crucible has been under development on an engineering scale in both radioactive and nonradioactive facilities at the Pacific Northwest Laboratory since 1968. Processing techniques, melting rates, canister designs, and the effects of the process on the canister and product are presented in this paper. 


\section{VITRIFICATION. OF NUCLEAR WASTE CALCINES \\ BY IN-CAN MELTING}

H. T. Blair

\section{INTRODUCTION}

The advantages of converting nuclear high-level liquid waste (HLLW) to borosilicate glass for disposal are well presented by Wayne Ross and John Mendel. (1) An in-can melting process for vitrification of such waste has been under development since 1968 and demonstrated on an engineering scale in both radioactive and nonradioactive facilities at the Pacific Northwest Laboratories (PNL). This process has been sufficiently developed by Battelle Northwest for the Energy Research and Development Administration (ERDA) that design of a HLLW solidification facility using the in-can melting process for vitrification is underway for implementation at a U.S. commercial fuel processing plant. The solidification concept, presented in Figure 1, uses a heated wall spray calciner $^{(2)}$ to convert the HLLW to calcine which is then fed directly into the incan melter along with a glass-forming frit. The in-can melting process uses the storage canister as the melting crucible to vitrify the mixture of calcined nuclear waste and glass-forming frit, thus, eliminating the need for a separate melter between the calciner and waste storage container. Also, eliminated is the need to transfer the melt from the melter to the storage container with the associated problems of valving and high loss of volatile species.

This paper presents some of the results of the in-can melter development work performed at the PNL during the past 18 months. Can designs, processing techniques, melting rates, and the effects of the process on the can and product are presented.

\section{EQU IPMENT AND PROCEDURES}

Figure 2 shows a typical can used for the engineering scale in-can melting development work. Although other alloys are being evaluated, all the cans used in the program were fabricated from $304 \mathrm{~L}$ stainless steel. The cans were made from 3 to $5 \mathrm{ft}$. lengths of 8 or $12 \mathrm{in.} \mathrm{diameter,} \mathrm{Schedule} 40$ pipe. Many of the cans contained internal, radial fins made from 1/4 in. thick, 304L stainless steel plate. Various numbers and configurations of fins were tested. 


\section{HLLW VITRIFICATION CONCEPT USING SPRAY CALCINER AND IN-CAN MELTER}

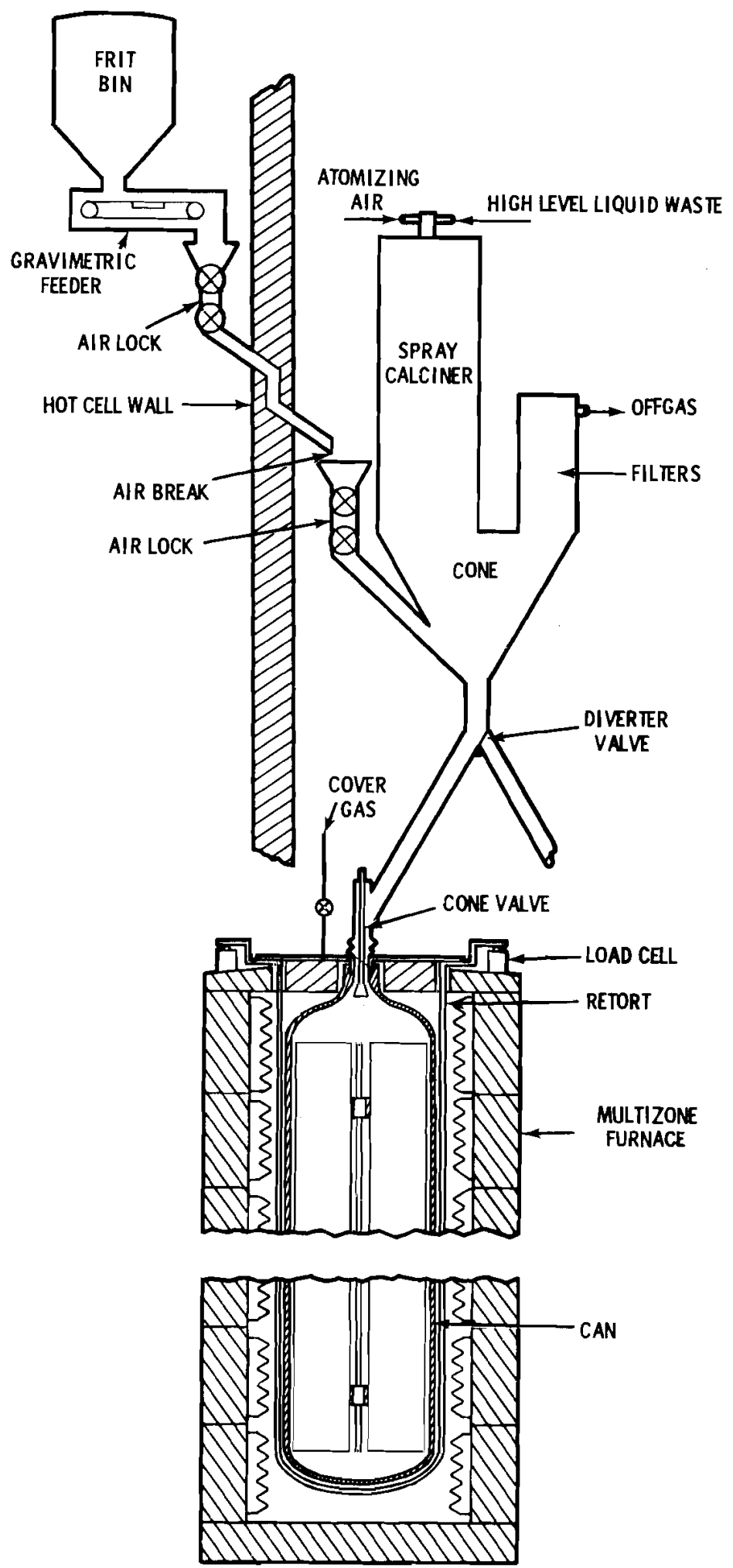

Fiqure 1 


\section{TYPICAL IN-CAN MELTER TEST CANISTER}
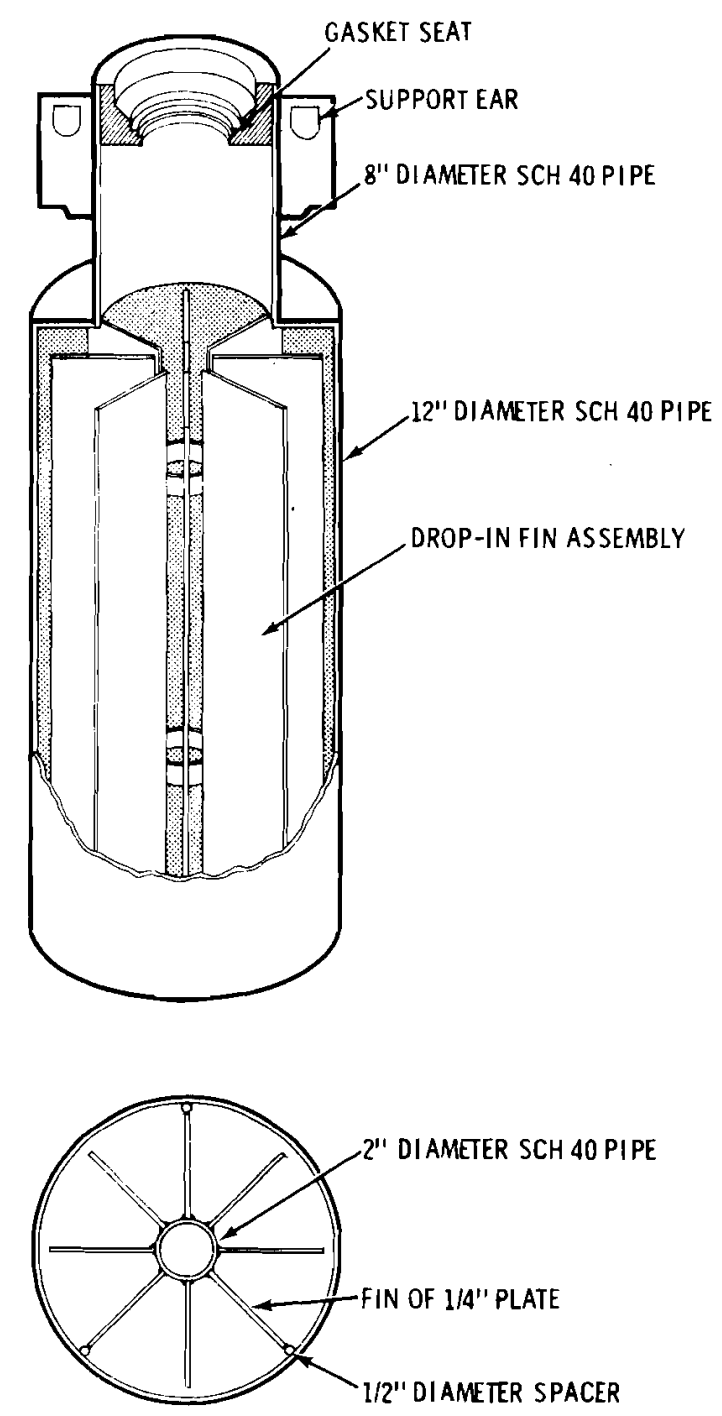

Finure? 
The fin design deternined to be most satisfactory through computer modeling ${ }^{(3)}$ and engineering scale tests was the simple drop-in assembly shown in figure 2. This assembly was designed to improve heat dissipation during storage so that larger diameter cans could be used. The assembly was not welded to the can but was centered by spacers located on the outside corners of several of the fins. The radial fins terminate $1 / 2$ inch from the wall to prevent hot spots from occurring at the wall while the can is in storage. During processing the can temperatures were monitored with thermocouples located on the exterior walls, at various positions on the fins (when they were present), and along the longitudinal axis of the cans.

The empty cans were usually suspended in the cool furnace by the support ears from a load cell as shown in Figure 3 . The furnace used for the work reported in this paper was a single zone, resistance heated furnace. Supporting the can from the top allowed the can to expand as it was heated without disturbing the connection to the calciner and located the load cells where they were readily accessible for maintenance in a hot cell.

When the in-can melter was operated in conjunction with a calciner, the can was coupled to the calciner outlet through a 4 in. diameter pipe which slopes at an angle of $60^{\circ}$ from horizontal to permit the location of more than one melter below the calciner. A metal bellows in this coupling section allows the can to hang free from the load cell. A silver plated, Incone $\mathbb{B}_{X-750 \text {, }}$ C-ring gasket was used to make the seal between the can and coupling section. The pressure in the melter was therefore the same as in the calcining system to which it was coupled. Operating pressures ranged from 1 to 10 inches of water vacuum.

The cans were heated to between 1025 and $1100^{\circ} \mathrm{C}$ in an air atmosphere and maintained in this temperature range during the melting operation. Batches consisting of different blends of frits and simulated nuclear waste calcines or concentrates were then fed to the melter at various rates. When calcine or concentrate was produced simultaneously to melter operation, frit was metered into the melter with a volumetric feeder at a rate proportional to the simulated waste oxide production rate. Off-gas from the melter was vented through the coupling section to the calciner filters. When the cans were full, they were held at the processing temperature for several hours to complete fining. Then they were cooled.

$\mathrm{R}$ Registered Trademark of the International Nickel Company, Inc. 
DEVELOPMENTAL IN-CAN MELTER AND COUPLING SECTION

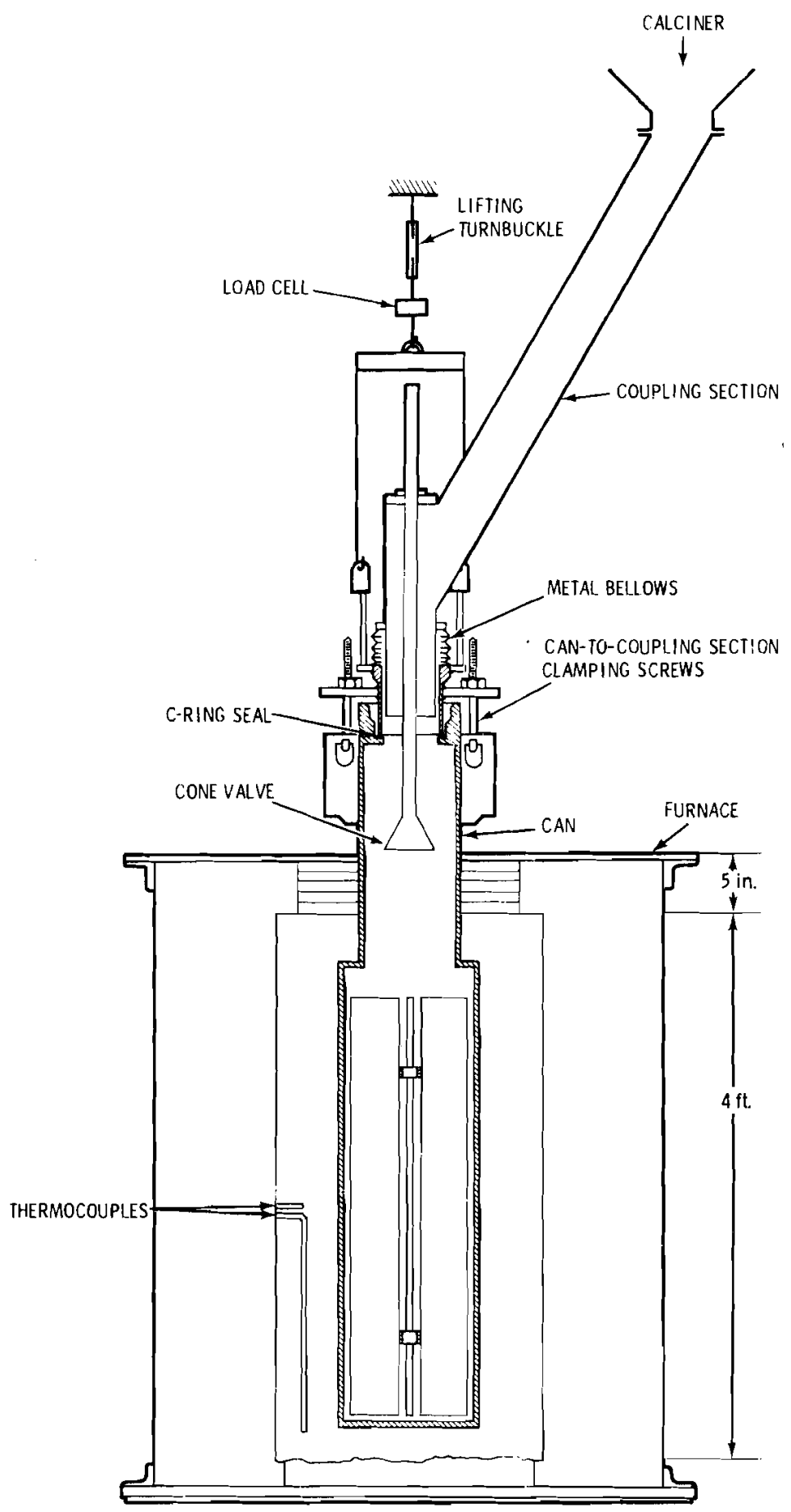

Finure 3 
For some tests, the cans were filled with batch and lowered into a preheated furnace or the heated can was rapidly charged with batch and the batch level was then maintained at a fixed level by further charging as melting proceeded. During many tests, the batch was fed to the melter only as fast as it was being melted, and during those tests where equipment development was the objective, the feed rates were often far below the melting capacity. Some cans of glass were allowed to cool at the natural cooling rate of the furnace. Others were annealed and cooled at a rate of 4 to $6^{\circ} \mathrm{C} / \mathrm{hr}$. Water and air quenching from $750^{\circ} \mathrm{C}$ to ambient temperature was also evaluated to minimize can material sensitization.

The in-can melting process just described will be modified by the use of a multizone furnace when vitrifying actual radioactive waste. Experience with in-can melting of radioactive waste was obtained at the PNL in 1970 when nearly 700 pounds of radioactive borosilicate glass were produced during two runs with the equipment shown in Figure $4 .{ }^{(4)}$ The vitrified product produced in the two cans had heat generation rates of 90 and 200 watts/liter respectively due to the radioactivity. As the melt accumulated in the can, the temperature below the melt level began to rise above the processing temperature. Power to the lower zones of the furnace was switched off and air cooling of these zones was necessary.

RESULTS

During the past 18 months, over $1560 \mathrm{~kg}$ of vitrified, simulated, nuclear waste were produced by 17 engineering scale in-can melting runs at the PNL. The first objective of the present program was to demonstrate the compatibility of the in-can melting process with the various calciners and concentrator that are being developed at the PNL. The melter was successfully operated while coupled directly to the heated wall spray calciner, the fluidized bed calciner, and the wiped film evaporator as shown in Figure 5 . However, liquid feeds such as the concentrate from the wiped film evaporator are not recommended for incan melting because they greatly reduce the melting capacity and increase the entrained solids loading in the off-gas.

The second objective of the in-can melter development program was to demonstrate that the process has a melting capacity in excess of the $48 \mathrm{~kg} / \mathrm{hr}$ required to melt the waste from the reference 5 metric tonne/day uranium fuel reprocessing plant. Some of the variables that were determined to have an effect on the melting rate were: 


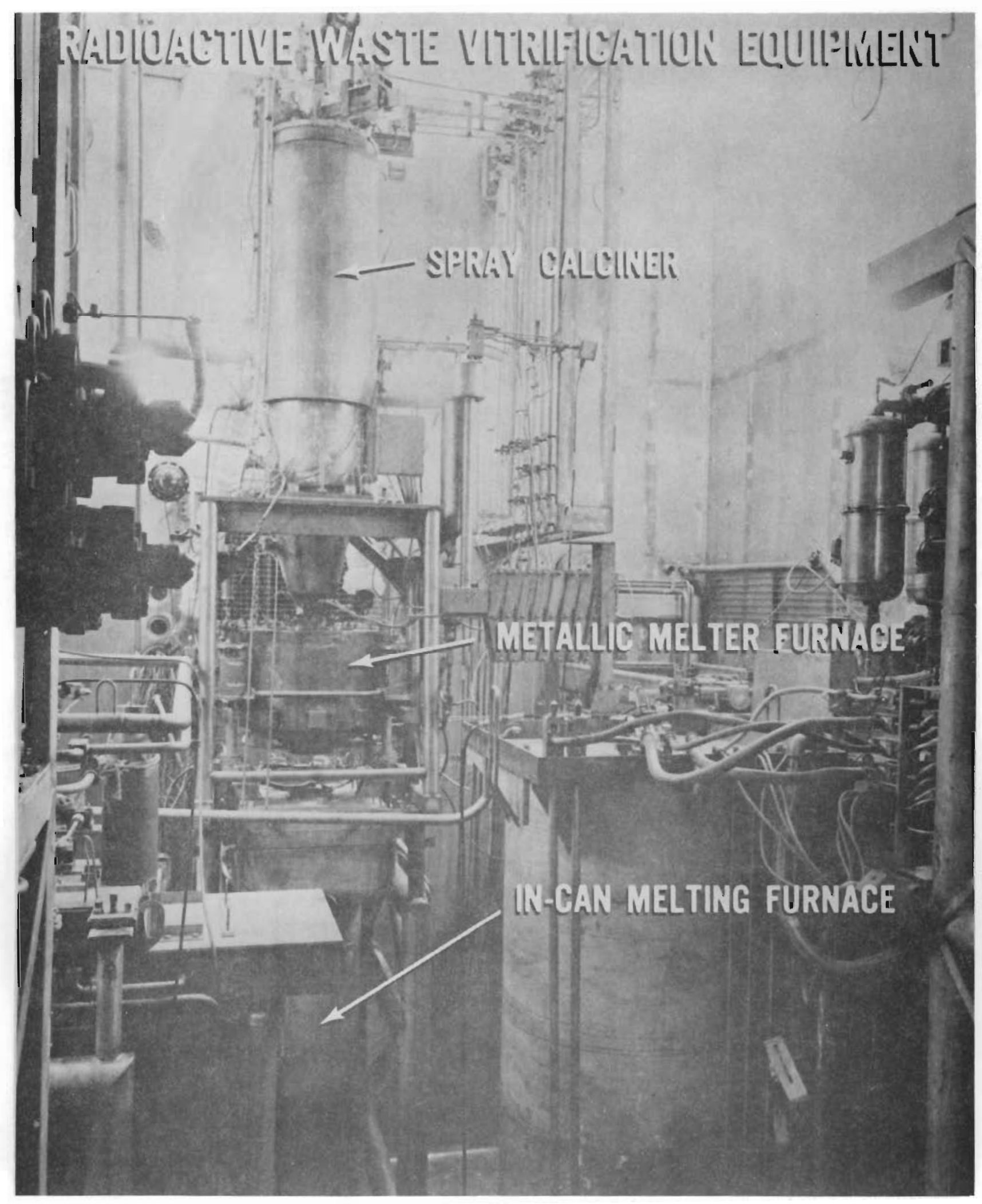

Figure 4 


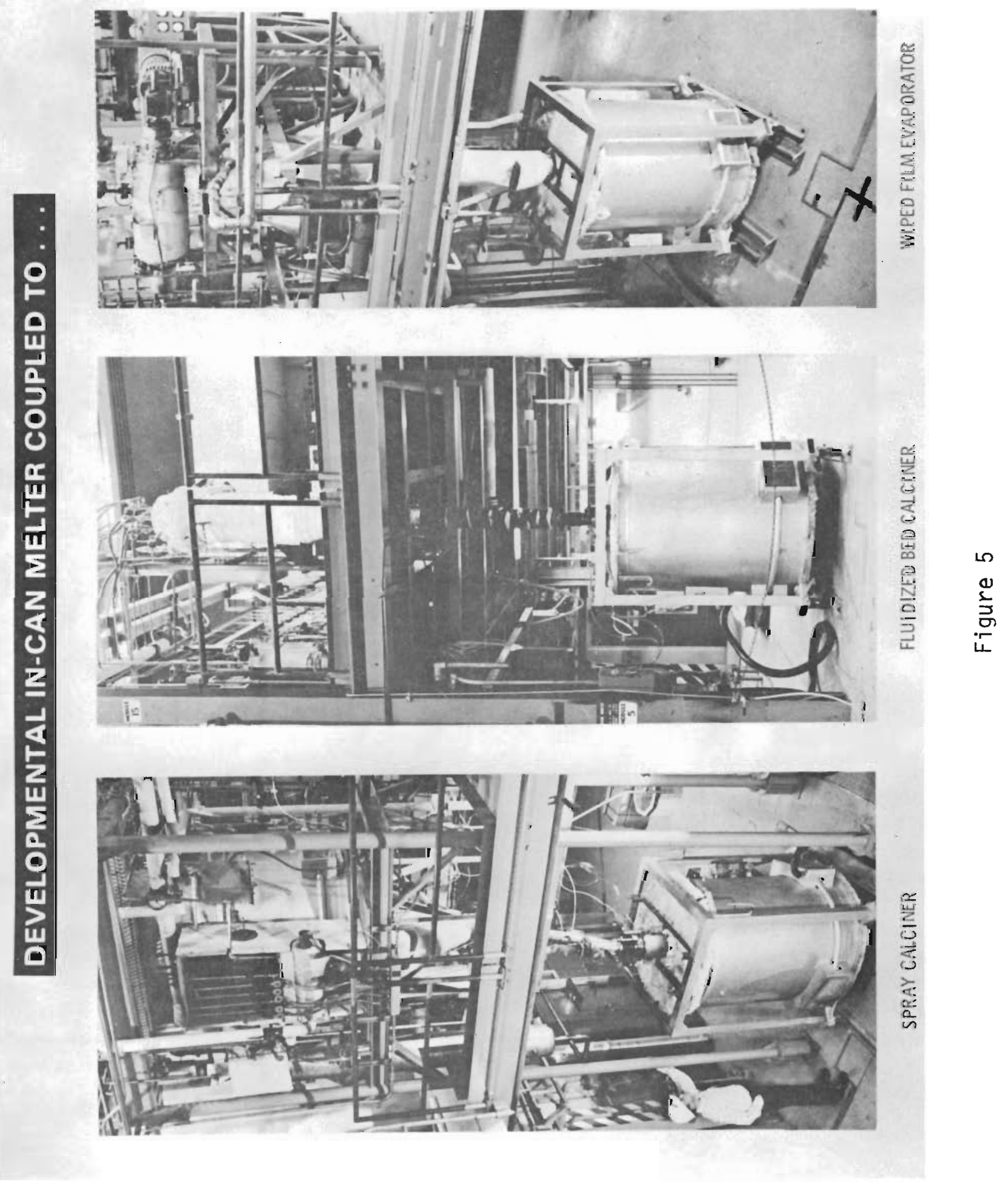


- Can diameter

- How the batch was fed to the melter

- Fins

- Furnace temperature

- Nitrate content of the calcine

- Addition of a reducing agent to the frit

- Calcine or wiped film evaporator concentrate type feed

Table I presents the melting rates demonstrated using the single zone furnace. The results are not directly comparable because some of the variables listed above were not constant for all demonstrations, but some general conclusions can be made.

It was initially believed that the melting rate could be increased for a given diameter can by having the batch in contact with more of the hot canister surface. Therefore, cans were precharged with batch or very rapidly charged with batch to the full level and then charged at a rate which maintained that level as melting proceeded. The melting rates obtained with this charging method are reported as a function of the batch level as well as time. This charging method was called the batch melting method and was compared to a rising level melting method in which the batch was charged to the melter at a rate equal to or just less than the rate at which it was being melted. The rising level melting method was determined to result in higher melting rates. The batch melting rate is believed to be less than the rising level melting rate because the $\mathrm{NO}_{x}$ and other gases released from the calcine as the batch is heated produce an insulating foam in the static batch while these gases are readily released at the surface with rising level melting. The batch melting process also produces voids as large as 2 in. in diameter in the vitrified product.

The use of fins in the canisters more than doubled the melting capacity of the in-can melter; however, they created charging problems. Because of heat losses from the top of the furnace and can, the top of the fins were so cool that batch would stick to them and not meit off. A bridge would form over the top of the fins. This problem was solved by locating a cone shaped baffle in the coupling section, as shown in Figure 3 , which is lowered into the neck of the can and deflects the batch away from the center of the fins and toward the hot walls of the can. When the 
table I. Melting Capacities of the In-Can Melter

\begin{tabular}{|c|c|c|c|c|c|}
\hline \multirow{2}{*}{$\begin{array}{l}\text { CAN } \\
\text { DIAMETER, } \\
\text { INCH }\end{array}$} & \multirow{2}{*}{$\begin{array}{c}\text { MELTER } \\
\text { CHARG ING } \\
\text { METHOD }\end{array}$} & \multirow{2}{*}{$\begin{array}{l}\text { NUMBER } \\
\text { OF } \\
\text { FINS }\end{array}$} & \multicolumn{2}{|c|}{ MELTING RATE } & \multirow{2}{*}{$\begin{array}{l}\text { TIME TO } \\
\text { MELT } 100 \mathrm{KG}, \\
\text { HR }\end{array}$} \\
\hline & & & $\mathrm{KG} / \mathrm{HR}$ & KG/HR-M & \\
\hline \multirow{5}{*}{8} & \multirow{2}{*}{$\begin{array}{l}\text { BATCH } \\
\text { DUMP }\end{array}$} & 0 & & 13.5 & 18.2 \\
\hline & & 8 & & 29 & 3.3 \\
\hline & \multirow{2}{*}{$\begin{array}{l}\text { RISING } \\
\text { LEVEL }\end{array}$} & 0 & 14 & & 7.1 \\
\hline & & 8 & 30 & & 3.3 \\
\hline & $\begin{array}{l}\text { Rising Level } \\
\text { Concentrate }\end{array}$ & 8 & 12 & & 8.3 \\
\hline \multirow{5}{*}{12} & \multirow{2}{*}{$\begin{array}{l}\text { BATCH } \\
\text { Dump }\end{array}$} & 0 & & 18 & 6.0 \\
\hline & & 8 & & 21 & 4.2 \\
\hline & \multirow{2}{*}{$\begin{array}{l}\text { RISING } \\
\text { LEVEL }\end{array}$} & 0 & 14.5 & & 6.9 \\
\hline & & 8 & 50 & & 2.0 \\
\hline & $\begin{array}{l}\text { Rising Level } \\
\text { CONCENTRATE }\end{array}$ & 8 & $13-19$ & & $5.3-7.7$ \\
\hline
\end{tabular}


baffle is retracted, it acts as a valve to seal the end of the coupling section while it is disconnected from the can.

The melting rates reported in Table I are considered conservative because they were established using nonradioactive, simulated waste which has no internal heat generation. High-level nuclear waste will generate from 15 to 150 watts/liter of vitrified product depending on the burnup of the fuel processed, the age of the waste, and the waste loading in the host glass. During the radioactive in-can melting demonstrations at the PNL in 1970, centerline temperatures reached $1040^{\circ} \mathrm{C}$ during melting in $8 \mathrm{in}$. diameter cans without fins while the walls were heated to only 900 to $950^{\circ} \mathrm{C}$ by the furnace. Even without the aid of this self heating the melting capacity of the in-can melter was demonstrated to be sufficient to handle the waste from the reference fuel reprocessing plant when a 12 in. diameter can containing a drop-in fin assembly was fed dry batch at a rate not exceeding the melting rate.

Corrosion of the $304 \mathrm{~L}$ stainless steel can by the melt during the process does not appear to be significant. The results of laboratory tests presented in Figure 6 , indicate a 3 to $6 \mathrm{mils} /$ day corrosion rate at $1050^{\circ} \mathrm{C}$. Examination of the walls and fins from processed cans verify these laboratory results. However, the 0.12 to $0.16 \mathrm{lb} / \mathrm{ft}^{2}$ of spall from the exterior surfaces of the cans heated in air is significant, for it would soon amount to a considerable accumulation in the furnace. A plasma sprayed coating of zirconia on the surface of the can was demonstrated to be effective for preventing spal1, ${ }^{(6)}$ but the coating process is expensive. The use of an inert cover gas around the exterior of the can during processing is being evaluated and will probably be reconimended if $304 \mathrm{~L}$ is the selected can material.

Because the annealing of the glass in the can was believed to result in sensitization of the 304L stainless steel, Huey tests were performed on samples taken from cans that had been cooled slowly through the sensitization temperature range. The maximum corrosion rate measured was $1.14 \mathrm{mils} / \mathrm{mo}$ for samples from the walls and $9.06 \mathrm{mils} / \mathrm{mo}$ for samples from the necks of the cans. The acceptable corrosion rate is $2 \mathrm{mils} / \mathrm{mo}$. Therefore, sensitization of the 304L cans by the in-can melting process exists only in the necks where anneaitiri 


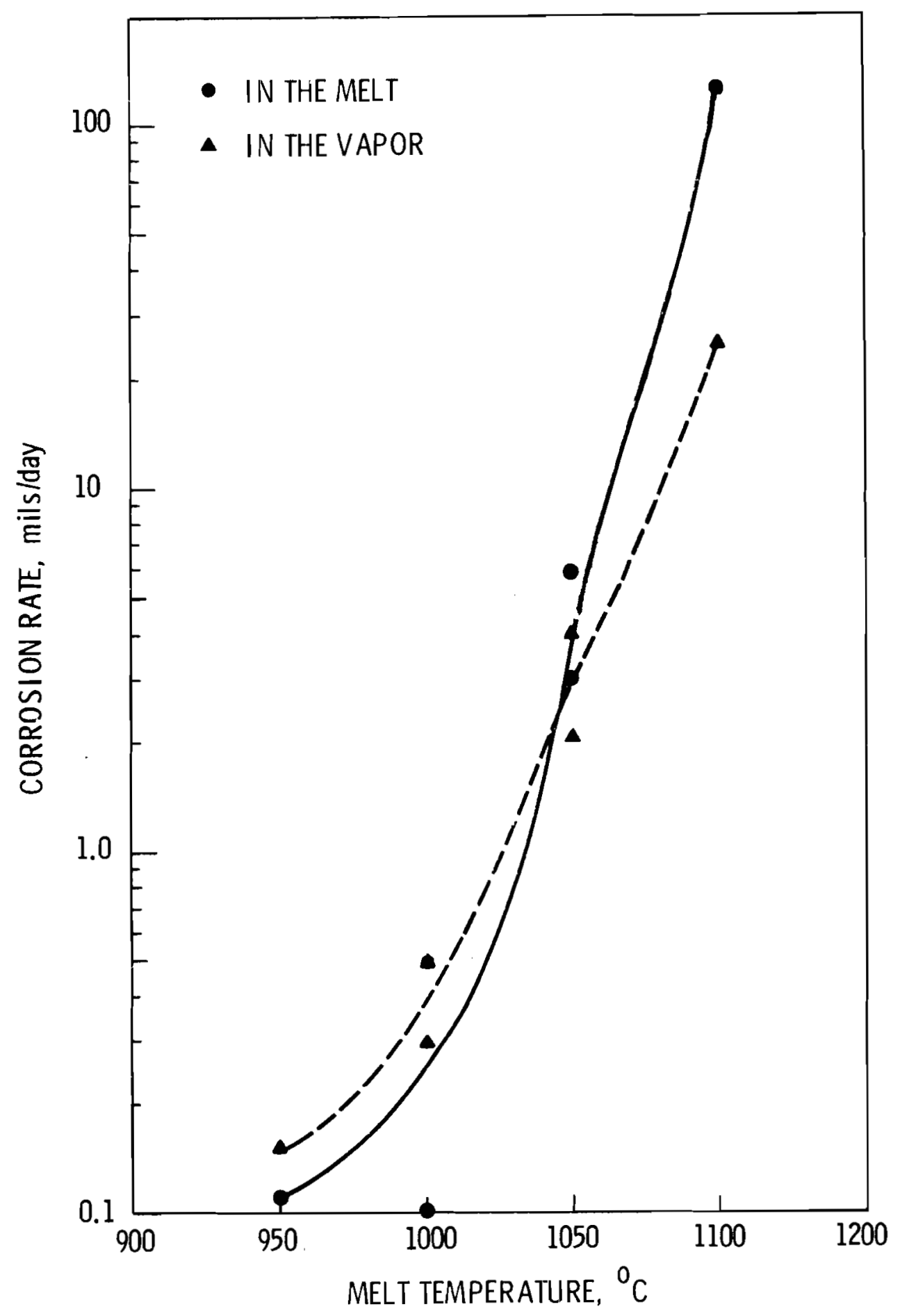

Fioure $E$

rorrosion Rate of $3 n a L$ Stainless steel in

simulated liclear laste Glass ielt 
following closure welding will probably be required to stress relieve and desensitize the weld area.

Because the glass bonds to the can walls and because the mean linear coefficient of thermal expansion of the glass is approximately $9 \times 10^{-6}{ }^{\circ} \mathrm{C}^{-1}$ while that of 304 stainless steel is $18 \times 10^{-6}{ }^{\circ} \mathrm{C}^{-1}$ in the range of 50 to $500^{\circ} \mathrm{C}$, the glass restrains the can from contracting during cooling. The glass is placed in compression and tensile stresses are placed in the can walls. Compressive forces on the glass enhance its integrity, but stresses in the steel reduce its resistance to stress corrosion cracking. The residual stresses were measured by bonding strain gages to a can wall and measuring the relaxation as cutouts were made around the gages. The measurements showed that the residual hoop stress in the can wall was 30,100 psi and the residual axial stress was 36,700 psi. These stress values substantiate calculations which predicted the can walls would experience moderate yielding during cooling. Although these residual stresses are not unique to the in-can melting process, the process may limit the possible techniques which can be used to reduce residual stresses in the storage canister. Some of these techniques include: 1) quenching the can of melt to contract the metal while the glass is still yielding, 2) cooling the can to a low enough temperature to cause sufficient yielding that it would be unstressed when warmed back to nomal storage temperatures, 3) placing a crushable liner between the glass and can wal1, and 4) annealing the borosilicate glass at the proper temperature to produce densification. The quality of the water in the storage basin can also be controlled to minimize corrosion. (7) If higher canister quality is required than can be provided by these methods, the canister can be overpacked.

Figure 7 shows examples of early and more recent products of the in-can melting process. The vitrified product has been broken away to reveal the inner structure. Early melts like the one on the left had a 3 to 6 in. layer in the bottom that was rich in $\mathrm{CeO}_{2}$ which is not completely dissolved in the glass at the in-can melter operating temperature. Cerium oxide is more dense than the melt and settles to the bottom when the total can is held at the processing temperature until completely filled. (8) The rest of the vitrified product was 


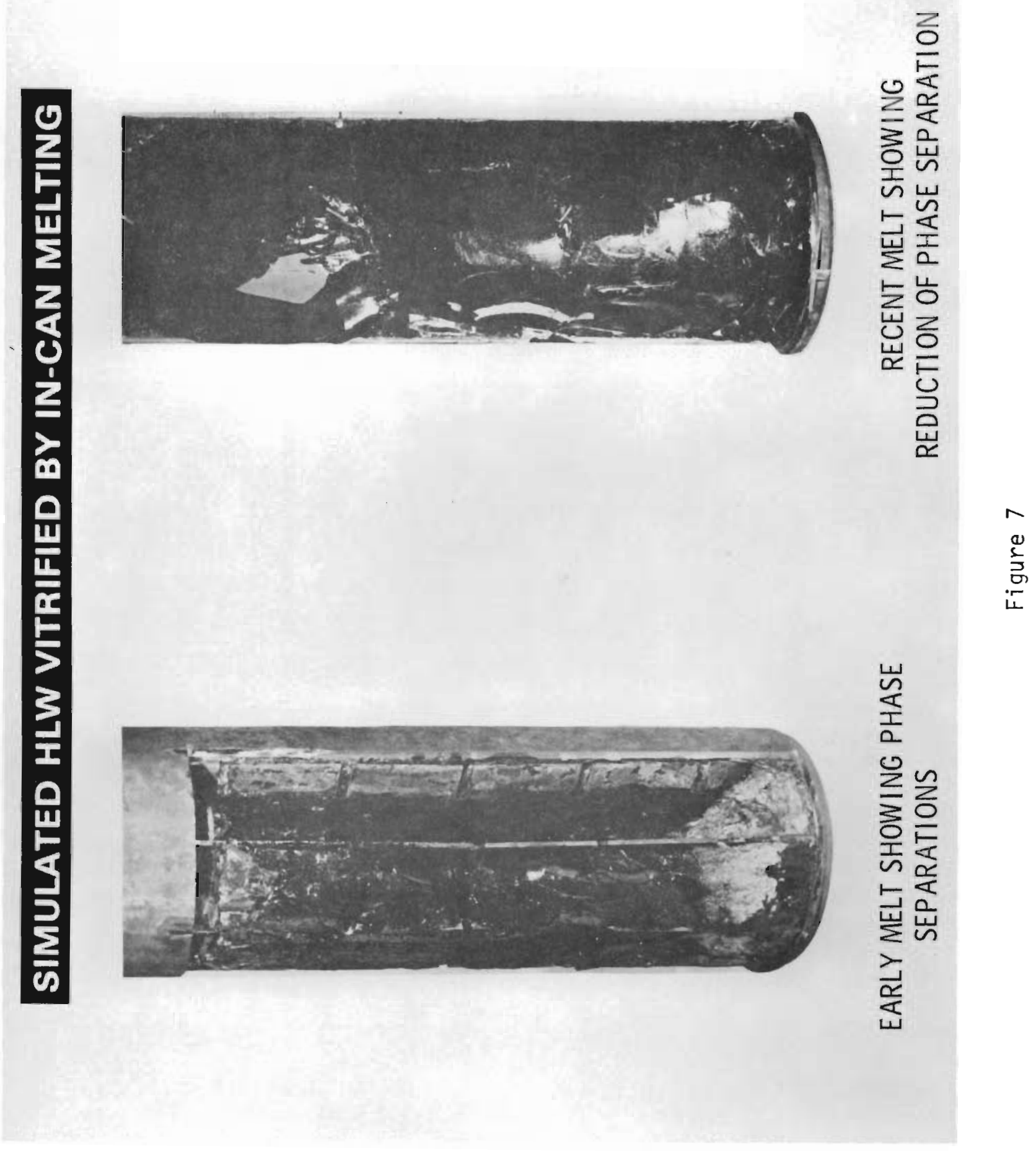


a dark glass in which various crystallites were uniformly dispersed. Some of these crystals have been identified as $\mathrm{CeO}_{2}, \mathrm{Zn}_{2} \mathrm{SiO}_{4}, \mathrm{SrMoO}_{4}$, and $(\mathrm{Zn}, \mathrm{Ni})(\mathrm{Fe}, \mathrm{Cr})_{2} \mathrm{O}_{4}$. On the top of the vitreous body was a thin layer of bright yellow crystalline material which was identified as a molybdate rich in $\mathrm{Na}, \mathrm{K}, \mathrm{Cs}$, and $\mathrm{Sr}$.

The can of glass on the right of Figure 7 is typical of melts recently produced using a new borosilicate frit composition and the addition of 1.5 wt\% powdered silicon metal to the batch to reduce the molybdates to an oxidation state that is soluble in the glass. (1). These changes in the batch eliminated the molybdate phase separation and reduced the amount of $\mathrm{CeO}_{2}$ that is undissolved. The reducing reaction also improved the melting rate by contributing heat to the batch during melting.

The density of the in-can melted product ranges from 3.0 to $3.7 \mathrm{~g} / \mathrm{cc}$ and the leach rate of recently produced glass has been as $10 \mathrm{w}$ as $1.3 \times 10^{-6} \mathrm{gm} / \mathrm{cm}^{2}$-day when determined by the $72 \mathrm{hr}$ Soxhlet leach test. (9)

\section{CONCLUSIONS}

Full scale demonstration and design for implementation at a U.S. commercial fuel reprocessing plant of the in-can melting process is in progress because of its relatively advanced state of development and because of the desirable features of this process that have been demonstrated on an engineering scale at the PNIL.

The in-can melting process is relatively simple. It combines the melting and storage container filling steps and eliminates the problems of melter deterioration and disposal, melt transfer and valving, and waste holdup in the melter.

Successful remote operation and maintenance of an in-can melter has been demonstrated while vitrifying actual high-level nuclear waste on an engineering scale.

The in-can melter can be closely coupled to a spray calciner, a fluidized bed calciner, or a wiped film evaporator. However, maximum melting rates and minimum operator attention are achieved when the feed to the melter is in the form of a dry calcine and frit blend. 
The melting capacity of the in-can melter is sufficient to handle the waste from a commercial fuel reprocessing plant having a throughput rate of 5 MTU/day. This capacity is attained by using a $12 \mathrm{in.} \mathrm{diameter} \mathrm{can} \mathrm{contain-}$ ing a drop-in fin assembly and by feeding dry batch at a rate not exceeding the melting rate.

Can material corrosion by the melt, spalling, and sensitization during the in-can melting process are insignificant or have been controlled. Residual stresses are present in 304L stainless steel cans that are filled with melted glass, but ways of reducing these stresses are known and are being evaluated.

The product of the in-can melting process is a durable, vitrified material in which phase separations have been controlled to assure high leach resistance. The addition of reducing agents to the batch to achieve this control has actually improved the performance of the melter. 


\section{REFERENCES}

1. W. A. Ross and J. E. Mendel, "Development of Glasses for High-Level Waste Solidification," Presented at 78th Annual Meeting of American Ceramic Society, Cincinnati, Ohio, May 1 - 5, 1976.

2. W. F. Bonner, H. T. Blair, L. S. Romero, "Spray Calcination of Nuclear Wastes," Presented at the 78th Annual Meeting of American Ceramic Society, Cincinnati, Ohio, May 1-5, 1976.

3. J. B. Duffy, "Canister Thermal Analysis," Quarterly Progress Report, Research and Development Activities, Waste Fixation Program, BNWL-1949. pp. 17 - 24, January 1976.

4. J. L. MCEl roy, "Evaluation of WSEP High-Level Waste Solidification Process," Waste Sol idification Program Summary Report, Vol. 11, BNWL-1667, BattelleNorthwest Laboratories, Richland, WA, June 1972.

5. W. A. Ross, "Pressurization Potential of Calcine," Quarterly Progress Report, Research and Development Activities, Waste Fixation Program, BNWL-1949, pp. 25 - 29, January 1976.

6. H. T. B1 air and W. A. Ross, "In-Can Melting," Quarterly Progress Report, Research and Development Activities, Waste Fixation Program, BNWL-1949, pp. 5 - 10, January 1976.

7. R. F. Maness, "Canister Corrosion Studies," Quarterly Progress Report, Research and Development Activities, Waste Fixation Program, BNWL-1994, June 1976.

8. J. E. Mendel, et al., Thermal and Radiation Effects on Borosilicate Waste Glasses, IAEA-SM-207/100 (BNWL-SA-5534). Vienna, Austria, Marcn $22-26$, 1976.

9. J. E. Mendel and J. M. Warner, "Waste Glass Leaching Measurements," Quarterly Progress Report, Research and Development Activities, Waste Fixation Program, BNWL-1741, pp. 5-8, Apri1 1973. 
No. of

Copies

OFFSITE

\section{UNITED STATES}

1 ERDA Chicago Patent Group 9800 South Cass Avenue Argonne, IL 60439

A. A. Churm

2 NRC Directorate of Licensing for Fuels and Materials 4915 St. Elmo Avenue Bethesda, MD 20014

Deputy Director for Fuels and Materials

S. H. Smiley

Chief, Technical Support Branch for Fuels and Materials

R. B. Chitwood

2 NRC Division of Materials and Fuel Cycle Facility Licensing Washington, DC 20555

Chief, Waste Management Branch

W. P. Bishop

J. S. Parry

1 ERDA Division of Biomedical and Environmental Research

Earth Sciences Branch Washington, DC 20545

W. G. Belter

1 ERDA Division of Environmental Control Technology Washington, DC 20545

W. E. Mott
No. of

Copies
1 ERDA Division of Physical Research Washington, DC 20545

D. W. Readey

9 ERDA Division of Nuclear Fuel Cycle and Production Washington, DC

F. P. Baranowski

C. R. Cooley

G. H. Daly

W. K. Eister

O. P. Gormley

C. Kuhlman

A. F. Perge

R. W. Ramsey

R. D. Walton

1 ERDA Idaho Operations Office P.0. Box 2708 Idaho Fa11s, ID 83401

K. K. Kennedy

1 ERDA Oak Ridge Operations Office P.0. BoX X Dak Ridge, TN 37830

E. H. Hardison

1 ERDA Savannah River Operations office P.0. Box A Aiken, SC 29801

R. L. Chandler

27 ERDA Technical Information Center 
No. of

Copies

2 Allied Chemical Corporation

550 - 2nd Street

Idaho Falls, ID 83401

J. A. Buckham

B. R. Dickey

3 Allied-General Nuclear Services

P.0. Box 847

Barnwe11, SC 29812

W. L. Godfrey

W. J. Price

c/o Bechtel Corporation

50 Beale Street

San Francisco, CA 94108

R. J. Cholister

1 Argonne National Laboratory

9700 South Cass Avenue

Argonne, IL 60439

M. J. Steindler

1 Bechtel Corporation

50 Beale Street

San Francisco, CA 94108

1 Brookhaven National Laboratory

Research Library, Reference Section Information Division

Upton, Long Island, NY 11973

M. Steinberg

1 C-E Refractories

Box 828

Valley Forge, PA 19482

A. W. Allen

1 Combustion Engineering, Inc.

Combustion Division

Windsor, CT 06095

R. Beekmann
No. of

Copies

3 Corning Glass Works

Technical Staffs Division

Corning, NY 14830

M. G. Britton

1 Dow Chemical Company (ERDA)

Rocky Flats Division

P.0. Box 888

Golder, C0 80401

D. L. Liegler

4 E. I. du Pont de Nemours and Co. Savannah River Laboratory

Aiken, SC 29801

R. F. Bradley

C. H. Ice

A. S. Jennings

J. A. Kelley

11 Electric Power Research Institute 3412 Hillview Avenue

P.0. Box 10412

Palo Alto, CA 94304

R. F. Williams

2 Environmental Protection Agency Technology Assessment Division (AW-559)

Office of Radiation Programs

Washington, DC 20460

G. L. Meyer

3 Exxon

Richland, WA 99352

S. J. Beard

L. T. Lakey

M. E. Spaeth

2 General Electric Company

175 Curtner Avenue

(M/C 160)

San Jose, CA 95125

R. G. Barnes

A. Carson 
ilo. of

Copies

2 General Atomic Company

P.0. Box 81608

San Diego, CA 92138

L. H. Brooks

J. J. Shefcik

4 Oak Ridge National Laboratory (ERDA)

Central Research Library Document Reference Section Central Research Library, ORNL Laboratory Records Dept., ORNL Laboratory Records Dept., ORINL-RC P.0. Box $X$

Oak Ridge, TN 378.30

1 Los Alamos Scientific Laboratory (ERDA)

P.0. Box 1663

Los Alamos, IIM 87544

G. Cowens

2 Nuclear Fuel Services, Inc. P.0. Box 124 West Valley, IY 14171

J. P. Duckworth, Plant Manager 6000 Executive Blvd., Suite 600 Rockville, MD 2085?

W. Lewis, Vice President

1 Pennsylvania State University Materials Research Laboratory Iniversity Park, PA 1680?

G. J. McCarthy

3 Sandia Laboratories A1buque rque, NM! 87107

R. W. Lynch

W. Weart

P. D. O'Brien
No. of

Copies

2 Inion Carbide Cornoration (H?l.)

Chemical Technolony nivision

P.0. Box $Y$

Oak Ridae, Til 37030

J. O. Blomeke

H. H. Godbee

1 Inion Carbide Corporation (OWI)

office of Waste Isolation

P.0. Box Y

Oak Ridae, TN 37830

c. ก. Zerby

1 Iniversity of Arizona

Mepartment of Nuclear Enaineering Tucson, . 12 857?.1

Roy Post

\section{ONSITE}

1 ERMA Richland nperations Office Proqrams Division

4 ERDA Pichland Operations Office Production and Waste Management Program Division

0. J. Elgert

R. B. Foranson

C. R. Palmer

D. J. Squires

1 ERחA Richland Operations Office Safety and Quality Assurance niv.

J. H. Strauh, nirector

4 Ptlantic Pichfield Hanfort Co.

R. E. Isaacson

D. C. Nelson

W. W. Shultz

File Copy

2 Westinghouse Hanford Comnany

P. E. Lerch

G. L. Pichardson 


\section{Eattelle-ilorthwest}

T. W. Ambrose

J. W. Bartlett

W. J. Bjorklund

H. T. Blair

W. F. Bonner

D. J. Bradley

J. R. Carrell

N. E. Carter

C. C. Chapman

T. D. Chikalla

R. D. Dierks

J. W. Finnigan

A. A. Garrett

T. A. Goldina

11. S. Hanson

H. S. Kelly

Y. B. Katayama

P. S. Kemper

R. P. Marshall

J. L. McElroy

J. E. Mendel

R. E. Niahtingale

D. E. Olesen

A. M. Platt

F. P. Roberts

W. A. Ross

J. L. Rusin

D. H. Siemens

S. C. Slate

R. P. Turcotte

H. H. Van Tuyi

J. H. Westsik, Jr.

L. 0. Williams

W. K. Hinegardner

Primary Author (15)

Technical Information (3)

Technical Publications 